Al-Manhaj: Jurnal Hukum dan Pranata Sosial Islam

Vol. : : 2 (1), 2020, 25-44

P-ISSN : 2686-1607

E-ISSN : 2686-4819

\title{
KONSEP MAQASID AL-SYARIAH DALAM KONTEKS GAME ONLINE DI MASYARAKAT
}

\author{
Dwi Runjani Juwita \\ Sekolah Tinggi Agama Islam Nahdlatul Ulama' Madiun \\ email: dwi.runjani@gmail.com
}

\begin{abstract}
The current development and globalization of this decade have been marked by rapid technological advances. Human welfare, which is demanded to be better and more advanced, triggers humans to discover new findings. One of the new findings found by humans is the internet. Technological progress is one of several measures of the development and progress of a country. The logical consequence at this level is that a country must be able to respond and implement the principle of technological progress as a standard if it wants to obtain a progressive state label, regardless of whether human resources in a country are ready or not in facing challenges and consequences in the future. Online games are part of technological advances that use the internet with a mechanism to connect between players online. With this online game there are a lot of madharat and mafsadat especially for teenagers and online game players because this game can bring fatigue, illness, laziness and something negative.
\end{abstract}

Keywords: Online Game, Maqasid al-Syariah

Abstrak: Perkembangan zaman dan globalisasi pada dasawarsa ini ditandai dengan kemajuan teknologi secara pesat. Kesejahteraan manusia yang dituntut untuk menjadi lebih baik dan maju memacu kreatifitas manusia dalam mencari temuan temuan baru. Temuan baru yang dihasilkan manusia adalah salah satunya internet. Kemajuan teknologi menjadi satu dari beberapa ukuran perkembangan dan kemajuan sebuah negara. Konsekwensi logis pada tataran ini, bahwa suatu negara harus mampu merespon dan menjalankan prinsip kemajuan teksnologi sebagai standar jika ingin memperoleh labelitas negara berkemajuan, terlepas apakah SDM dalam suatu negara tersebut siap atau tidak dalam 
menghadapi tantangan dan konsekwensi dikemudian hari.Game Online merupakan bagian dari kemajuan teknologi yang menggunakan internet dengan mekanisme menghubungkan antar pemain secara online. Dengan adanya game online ini banyak sekali madharat dan mafsadat terutama bagi para remaja dan para penggiat game online karena permainan ini bisa mendatangkan kelelahan,sakit,bermalas-malasan dan sesuatu yang bersifat negatif.

Kata Kunci: Maqasid al-Syariah, Game Online, Masyarakat

\section{PENDAHULUAN}

Kemajuan teknologi lengkap dengan fitur informasi yang selalu terupdate merupakan sebab manusia dapat menjelajahi sudut dunia dan menggali informasi sesuai dengan keinginannya baik yang akan dikontektualisasikan dalam bentuk pengembangan sains, bisnis (jual beli) maupun yang sekedar untuk merefreshkan diri dalam bentuk game online. Dalam pengembangan sains fungsi kemajuan teknologi membantu memberikan informasi secara baik dan mendalam. Dalam hal bisnis (jual beli) kemajuan teknologi memberi langkah kongkrit untuk memperdekat jarak dan mempermudah transaksi antara penjual dan pembeli dalam bentuk jual beli online. Setiap kebutuhan akan suatu barang serta harga yang diinginkan konsumen telah diakomodir dalam suatu aplikai jual beli online.

Berbeda dengan fungsi teknologi sebagai informasi sains dan bisnis, fungsi kemajuan teknologi (internet) menawarkan layanan hiburan modern dalam bentuk game online yang dapat diakses oleh seluruh golongan manusia selama memiliki media elektronik yang terkoneksikan dengan internet. Sebagaimana pada hasil survei yang dilakukan oleh asosiasi penyelenggara jasa 
internet indonesia (APJII) terhadap penetrasi dan profil perilaku pengguna internet tahun 2018 diketahui pengguna internet pada tahun 2018 berjumlah 171,17 jt atau 64,8 \% dari 264,16 jt jumlah penduduk indonesia. Dari jumlah pengguna jasa inter tersebut ditemukan populasi terbesar pengguna internet berusia 15-19 tahun dengan prosentase $91 \%$ yang merupakan usia produktif sedangkan pada urutan ke enam terdapat pada anak yang berusia 10-14 tahun dengan prosentase 66,2\%.1. Lemahnya sistem filterisasi pengguna internet khususnya game online mempengaruhi pola perilaku seseorang sebagai makhluk sosial dan beragama. Perubahan yang fundamental dari permainan tradisional dengan karakter hubungan sosial yang kuat serta sebagai warisan budaya indonesia menuju pada hiburan modern seperti game online sebagai bukti konkret akan kecanggihan teknologi internet dengan cepat dan pesat merambah disetiap dimensi waktu, tempat dan kondisi.

Konsekwensi perubahan yang dihadapi tidak hanya perubahan media atau obyek hiburannya semata yaitu dari permainan tradisional menuju modern, melainkan yang sangat subtansi dan membahayakan terdapat pada perubahan hubungan sosial, psikologi sebagai individu, rendahnya memfungsikan waktu kepada yang lebih bermanfaaf serta perubahan pada manusia sebagai makhluk bertuhan (beragama). Pergeseran nilai empati dan solidaritas secara signifikan berubah menjadi sifat apatis dan skeptis dalam kaitanya sebagai makhluk sosial dan kondisi ini

1 Asosiasi Penyelenggara Jasa Internet Indonesia (APJII), "Responden Survey Nasional Penetrassi Pengguna Internet 2018". 
sebagai pintu terbentuknya manusia yang berkarakter hedonisme. Kecanduan game online merupakan salah satu jenis kecanduan yang disebabkan oleh teknologi internet atau yang lebih dikenal dengan internet addictive disorder.

Internet dapat menyebabkan kecanduan, salah satunya adalah Computer game Addiction (berlebihan dalam bermain game). Dalam teori behavioral disebutkan pribadi sehat adalah pribadi yang dapat merespon stimulus di lingkungan secara tepat dalam bertingkah laku untuk memenuhi kebutuhannya dan dapat mengembangkan reinforcer internal disamping eksternal serta memiliki self-control yang baik. Pribadi yang tidak sehat adalah apabila tingkah laku individu kurang atau tidak memuaskan sehingga membawa konflik diri dengan lingkungannya. Dengan kata lain disebut perilaku maladaptif (perilaku yang tidak tepat) yang terbentuk melalui proses interaksi dengan lingkungannya. Manusia dalam hal ini adalah remaja yang mendedikasikan sepenuh waktunya untuk game online mengalami dehidrasi nilai sensitifitas terhadap lingkungan disekitarnya. Secara kongkret dapat dilihat pada lemahnya respon anak terhadap panggilan orang tua serta menurunnya itensitas komunikasi seseorang.

Dalam kaitanya pemahaman makna maslahat dan mafsadat secara zati dikatakan bahwa suatu perbuatan dikatakan memiliki maslahat baik secara pribadi maupun umum apabila perbuatan tersebut mendatangkan keuntungan, meningkatnya pengetahuan, kelezatan, kesenangan, kesehatan dan lain sebaginya. Sedangkan suatu perbuatan yang dapat mendatangkan mafsadat apabila 
perbuatan tersebut berimplikasi terhadap kerugian, kebodohan, kepedihan, keletihan, sakit dan lain-lain yang memiliki konotasi negatif. $^{2}$

Dari resiko yang ditimbulkan oleh kecenderungan seseorang dalam menggunakan internet untuk game online, maka bagaimanakan konsep maqasid al-syariah yang merupakan landasan utama kehidupan seorang muslim yang baik mampu merespon fenomena tersebut terlepas sebagai legitimisai maupun filterisasi. Desain pada penelitian ini adalah penelitian diskriptif, dengan menggunakan teknik kualitatif, yaitu suatu proses yang mencoba untuk mendapatkan pemahaman yang lebih baik mengenai kompeksitas yang ada dalam interaksi manusia dan secara khusus untuk memperoleh jawaban atau informasi mendalam tentang sosial dan kepercayaan masyarakat serta perubahan budaya sosial. Tulisan ini diharapkan mampu memberikan gambaran komprehensif mengenai pemahaman terhadap perkembangan baru mengenai studi hukum Islam, dan fenomenologi perubahan sosial yang disebabkan oleh perkembangan teknologi pada penggiat game online perspektif Islam dengan konsep maqasid al-syariah sehingga akan diketahui ciri-ciri khas berbagai pendekatan baru yang tentunya mampu memberi gambaran nyata untuk mencapai implementasi keilmuan dalam realitas kontekstual. Di samping itu, penelitian ini tidak saja diharapkan mampu memberikan perspektif yang lebih luas mengenai pembelajaran terhadap kemungkinan mengembangkan

2 Muasthafa Ahmad al-Zarqa, Hukum Islam dan Perubahan Sosial: Studi Komparatif Delapan Mazhab Fiqh (Jakarta : Riora cipta, 2000), 36. 
metode tapi juga menekankan pemahaman tentang cara bagaimana melihat Islam dilihat dari perspektif lain.

\section{GAME ONLINE}

Teknologi game online berawal dari penemuan metode networking computer tahun 1970-an oleh militer Amerika. Pada game online ini pertama kali menggunakan jaringan LAN atau Local Area Network tetapi sesuai dengan perkembangan teknologi akhirnya game oline menggunakan jaringan yang lebih luas lagi seperti www atau world wide web atau yang lebih dikenal dengan internet yang bisa diakses dengan menggunakan nirkabel, untuk bisa memainkan game online terlebih dahulu kita harus menginstal program game tersebut, untuk memulai game online terlebih dahulu kita harus register atau mendaftar dan kita langsung dapat memainkannya.

Game online adalah gabungan dari dua kata yang berasal dari bahasa inggris. Game artinya permainan dan online artinya adalah daring (dalam jaringan). Jika dua kata ini digabungkan, maka akan terbentuk suatu makna baru yaitu sebuah jenis video permainan yang hanya dapat dijalankan apabila suatu perangkat yang digunakan untuk bermain game terhubung dengan jaringan internet. Game online biasanya memungkinkan suatu pemain (player) game untuk saling terhubung dengan pemain lain. Sehingga hal itu memungkinkan para pemain melakukan kontak, baik dalam bentuk permainan (seperti; pukul-memukul, tembakmenembak) ataupun berkirim pesan. 
Berkaitan dengan pengertian game online Young mengemukakan bahwa game online adalah permainan dengan jaringan, dimana interaksi antara satu orang dengan yang lainnya untuk mencapai tujuan, melaksanakan misi, dan meraih nilai tertinggi dalam dunia virtual. Lebih lanjut dapat dikatakan game online adalah suatu permainan yang dimainkan dikomputer dan dilakukan secara online (melalui internet) dan bisa dimainkan oleh banyak orang secara bersamaan. ${ }^{3}$

Selanjutnya Andrew Rollings dan Ernest Adams, menjelaskan bahwa game online lebih tepat disebut sebagai sebuah teknologi dibandingkan sebagai sebuah genre atau jenis permainan, sebuah mekanisme untuk menghubungkan pemain bersama dibandingkan pola tertentu dalam sebuah permainan. Pendapat tersebut memiliki makna bahwa game online bukan hanya sekedar sebuah permainan sederhana melainkan sebuah kemajuan teknologi yang mengedepankan mekanisme untuk dapat menghubungkan antar pemain. Berdasarkan pendapat ahli tersebut dapat disimpulkan bahwa game online merupakan suatu bentuk permainan yang dapat dimainkan oleh banyak pemain melalui koneksi internet. 4

\section{JENIS GAME ONLINE YANG TRENDING DI INDONESIA}

Di era internet dan smartphone yang makin canggih, bermain game bisa dilakukan di mana saja dan kapan saja. Ada

${ }^{3}$ Kimberly S Young, Internet addiction: A Handbook and Guide to Evaluation and Treatment ( Hoboken, NJ: John Wiley \& Sons, 1999).

${ }^{4}$ Andrew Rollings dan Ernest Adams, on Game Design (USA: New Rider Publishing 2003), 499. 
banyak sekali game Android yang bisa dimainkan secara multiplayer dan menyenangkan. Namun setidaknyaterdapat lima besar produk game online terbaik yang diakses oleh banyak kalangan penggiat game online, diantaranya adalah. ${ }^{5}$

1. Mobile Legends: Bang Bang merupakan game android yang sangat populer di Indonesiaa. game ini sangat digandrungi banyak kalangan karena bergenre MOBA (Multiplayer online battle arena) ini dapat dimainkan secara online dengan koneksi terbatas dan spesifikasi yang tidak terlalu tinggi. Gim ini juga sangat membutuhkan kerjasama tim yang baik.

2. PUBS Mobile, permainan kontorversi ini mempunyai satu tujuan yaitu bertahan hidup sebaik mungkin menjadi orang yang terakhir. Pemain akan terjun dari sebuah pesawat ke sebuah pulau berukuran besar, dan diharuskan mengambil senjata serta peralatan untuk bertahan. Permainan ini juga bisa dimainkan bersama teman hingga 4 orang, dan dilengkapi voice chat dalam game jadi kamu bisa sambil berkomunikasi.

3. Garena Free Fire: Gim yang sangat mirip dengan PUBG, Free Fire Battlegrounds sama-sama harus bertahan hidup melawan musuh pulau hingga menjadi orang yang bisa hidup di akhir game. Sama seperti PUBG, Free Fire bisa dimainkan bersama teman hingga 4 orang, dan dilengkapi voice chat.

4. Garena AOV - Arena of Valor: Action MOBA Gim yang mirip dengan Mobile Legends, gim MOBA memang saat ini sedang disukai

5 Bernhart Farras, "10 Game Online Android Terbaik dan Terpopuler Untuk Mabar", www.cnbcindonesia.com, 2019. 
oleh banyak orang, dan pada akhirnya developer terkenal seperti Garena ikut merilis game dengan genre MOBA dengan nama Arena of Valor.

5. COC (Clash Of Clans): Walaupun bukan gim online terbaik dari android yang baru dirilis, COC selalu menjadi game terbaik di genrenya, game ini berhasil menceritakan tentang strategi yang dilakukan untuk menyerang desa lawan agar bisa membangun desa pengguna.

\section{GAME ONLINE DAN PENGARUHNYA TERHADAP PERILAKU REMAJA}

Perkembangan teknologi kemajuan teknologi informasi pada kehidupan umat manusia dengan segala peradaban dan kebudayaan. Perubahan ini juga memberikan dampak yang begitu besar terhadap transformasi nilai nilai yang ada dimasyarakat. Khususnya masyarakat adat dan kebudayaan timur seperti indonesia. Masyarakat yang sempurna dalam pandangan al-Farobi adalah masyarakat yang mengandung keseimbangan di antara unsur-unsurnya. Perbedaaanya hanyalah kalu unsur-unsur masyarakata itu mempunyai kebebasan individual yang lebih besar, maka dalam manusia unsur-unsurnya itu lebih dikuasai dan diperintah oleh pusatnya. ${ }^{6}$ Saat ini diindonesia dapat kita saksikan begitu besar pengaruh kemajuan teknologi terhadap nilai nilai kebudayaan yang dianut masyarakat, baik diperkotaan maupun dipedesaan, seperti televisi, telepon, radio, telpon genggam (Hp), Gagdet, Ipad, bahkan internet bukan hanya melanda masyarakat di 2004), 169.

6 Ahmad syadali dan mudzakir, Filsafat Umum (Bandung: CV Pustaka Setia, 
perkotaan namun juga dapat dinikmati masyarakat dipelosok pelosok pedesaan.

Erich Fromm mengemukakan bahwa sistem masyarakat dapat berubah secara mendasar. Perubahan akan mengakibatkan perubahan-perubahan karakter manusianya. Menurut Fromm, relasi anatara sistem masyarakat dan eksistensi manusia mengikuti beberapa proposisi. Pertama, manusia mempunyai kodrat esensial bawaan. Kedua, sistem masyarakat diciptakan oleh manusia untuk memenuhi kodrat esensial ini. Ketiga, tidak satupun bentuk sistem masyarakat yang pernah diciptakan berhasil memenuhi kebutuhan-kebutuhan dasar eksistensi manusia. Keempat, eksistensi manusia sangat mungkin menciptakan sistem masyarakat semacam itu. ${ }^{7}$

Setiap manusia memiliki perilaku dan perilaku merupakan cermin dari diri manusia itu sendiri. Perilaku timbul dari motif yang ada di dalam manusia. Dengan demikian bahwa perilaku atau aktifitas-aktifitas itu merupakan manifestasi kehidupan psikis. Menurut Jogiyanto HM Perilaku (Behaviour adalah tindakantindakan (actions atau reaksi-reaksi (reactions) dari suatu obyek atau organisme. ${ }^{8}$ Skiner (1938) seorang ahli psikologi, merumuskan bahwa perilaku merupakan respon atau reaksi seseorang terhadap stimulus (rangsangan dari luar).

${ }^{7}$ Eka Nova Irawan, Pemikiran Tokoh-tokoh Psikologi dari Klasik sampai Modern (Yogyakarta: IRCisos, 2015), 172.

${ }^{8} \mathrm{HM}$ Jogiyanto,Sistem Informasi Keperilakuan (Yogyakarta: Andi Offet 2007), 11. 
Menurut Bimo Walgito ada tiga cara pembentukan perilaku yakni: ${ }^{9}$

1. Cara pembentukan perilaku dengan kondisioning atau kebiasaan. Salah satu cara pembentukan perilaku dapat ditempuh dengan kondisioning atau kebiasaan.

2. Pembentukan perilaku dengan pengertian (insight). pembentukan perilaku dapat ditempuh dengan pengertian atau insight. Cara ini berdasarkan atas teori belajar kognitif, yaitu belajar dengan disertai adanya pengertian.

3. Pembentukan perilaku dengan menggunakan model. Pembentukan perilaku masih dapat ditempuh dengan menggunakan model atau contoh. Kalau orang bicara bahwa orang tua sebagai contoh anak - anaknya, pemimpin sebagai panutan yang dipimpinnya, hal tersebut menunjukan pembentukan perilaku dengan menggunakan model.

Dalam perspektif Skinner, tingkah laku bukan sekedar respon terhadap stimulus, tetapi juga suatau tindakan yang disenagaja atau operan. Dalam hal ini, operan dipengaruhi oleh hal-hal yang terjadi sesudahnya. Operan sendiri adalah sejumlah perilaku atau respons yang membawa efek sama dengan lingkungan terdekat. Jadi operant conditioning melibatkan pengendalian konsekwensi. Setiap tingkah laku berada dianatar dua pengaruh, yaitu pengaruh yang mendahului (antecedent) dan mengikutinya (konsekwensi).10

9 Bimo Walgito, Psikologi Sosial : Suatu Pengantar (Yogyakarta : Fakultas Psikologi UGM, 1980), 13.

10 Bimo Walgito, 200. 
Menurut Merskin, Dalam Media Dependency Theory terdapat sistem tiga pihak yang menghasilkan Efek pada remaja yaitu:

1. Hubugan Ketergantungan - Media sebagai alat komunikasi dalam penelitian ini mengenai game online yang dapat memberikan pengaruh yang sangat bersar terhadap remaja sehingga dapat terjadi suatu ketergantungan pada diri remaja tersebut.

2. Audience yaitu pengguna media dalam penelitian ini adalah Remaja yang menentukan untuk memilih dan menggunakan game online.Efek Behavioral - Perilaku Emosional yaitu reaksi yang ditunjukkan oleh remaja ketika ia merasakan sesuatu amarah terhadap permainan game online seperti kekalahan dari permainan tersebut. Sifat pemarah yang tidak bisa dielakkan ini dapat merugikan orang lain dan bisa mengakibatkan yang sangat fatal. - Perilaku Agresif yaitu luapan emosi sebagai reaksi terhadap kegagalan remaja dalam melawan lawan main dari bermain game online yang ditampakkan dalam bentuk pengrusakan terhadap orang atau benda.

\section{HAKIKAT MAQASID AL-SYARIAH}

Dari segi bahasa maqasid al-syariah berarti maksud atau tujuan disyariatkan hukum Islam. Karena itu, yang menjadi bahsan utama di dalamnya adalah mengenai maslah hikmat dan ilat 
ditetapkannya suatu hukum. ${ }^{11}$ Tujuan suatu hukum harus diketahui dalam rangka mengetahui, apakah suatu kasus masih dapat diterapkan berdasarkan satu ketentuan hukum, karena adanya perubahan struktur sosial, hukum tersebut tidak dapat diterapkan. Dengan demikian "pengetahuan tentang maqasid syariah menjadi kunci bagi keberhasilan mujtahid dalam ijtihadnya". Tentu yang dimaksud dengan persoalan hukum disini adalah hukum yang menyangkut bidang muamalah.

Tujuan Allah Swt mensyariatkan hukumnya adalah untuk memelihara kemaslahatan manusia, sekaligus untuk menghindari mafsadat, baik di dunia maupun di akhirat. Maslahat dan mafsadat yang dapat dianggap sebagai standar perintah dan larangan dalam syariat adalah maslahat dan mafsadat yang sesuai dan tidak bertentangan dengan maqasid syariah. Tujuan tersebut hendak dicapai melalui taklif, yang pelaksanaannya tergantung pada pemahaman sumber hukum yang utama, al-Qur'an dan Hadits. Dalam rangka mewujudkan kemaslahatan di dunia dan akhirat, berdasarkan penelitian para ahli ushul fiqh, ada lima unsur pokok yang harus dipelihara dan diwujudkan, kelima pokok tersebut adalah agama, jiwa, akal, keturunan, dan harta. Seorang mukallaf akan memperoleh kemaslahatan, manakala ia dapat memelihara kelima aspek pokok tersebut, sebaliknya ia akan merasakan adanya mafsadat, manakala ia tidak dapat memelihara kelima unsur dengan baik. ${ }^{12}$

${ }^{11}$ Ahmad Raisuni, Nazhariyat al-Maqasyid 'Inda al-syatibi (Rabath: Dar al-Aman, 1991), 67.

12 Fathurrahman djamil, Filsafat Hukum Islam (Ciputat: Logos Wacana Ilmu, 1999), 125. 
Guna kepentingan menetapkan hukum, kelima unsur diatas dibedakan menjadi tiga peringkat, daruriyyat, hajiyyat, dan tahsiniyat. Pengelompokan ini didasarkan pada tingkat kebutuhan dan skala prioritasnya. Urutan peringkat ini akan terlihat kepentinganna, manakala kemaslahatan yang ada pada masingmasing peringkat satu sama lain bertentangan. Dalam hal ini peringkat daruriyat menempati urutan pertama, disusul oleh hajiyyat, kemudian disusul oleh tahsiniyyat. Namun disisi lain dapat dilihat bahwa peringkat ketiga melengkapi peringkat kedua, dan peringkat kedua melengkapi peringkat pertama. Dalam islam perbuatan pribadi memiliki pertanggung jawaban yang akan diberikan. Perbuatan seseorang tidak boleh bertentangan dengan norma-norma akhlak yang mulia. Jadi budi pekerti yang baik itu tidak bisa dipisahkan dari ajaran agama. Ajaran agama pun tidak dipisahkan dari apa yang disebut dengan hukum. ${ }^{13}$

\section{MAQASID AL-SYARIAH DALAM KONTEKS GAME ONLINE}

1. Konsep Penjagaan Agama (Hifz-Ad-Din)

Agama adalah sesuatu yang sangat penting bagi kehidupan manusia. Agama merupakan tolok ukur setiap tindakan dan perbuatan yang dilakukan oleh setiap muslim. Menjaga agama tidak hanya terkait dengan ibadah saja, tapi juga menyangkut kegiatan manusia sehari-hari apakah kegiatan tersebut bermanfaat atau tidak. Islam bukanlah agama yang membelenggu

13 Ibrahim Hosen, Bunga Rampai dari percikan Filafat Hukum Islam (Jakarta: Yayasan Institut Ilmu al-Qur'an (IIQ), 1997), 15. 
manusia. Islam juga bukanlah agama yang utopis, yang memperlakukan manusia seolah-olah malaikat yang tidak memiliki keinginan atau nafsu sama sekali. Islam memperlakukan manusia sesuai dengan naluri kemanusiaannya. Islam sangat memberikan keluasan dan kelapangan bagi manusia untuk merasakan kenikmatan hidup. Namun demikian, tidak semua hiburan (al-lahwu) mendapatkan tempat dalam agama Islam. Islam hanya membolehkan jenis-jenis hiburan yang di dalamnya terdapat unsur-unsur pendidikan, kesehatan, dan nilai-nilai moral lainnya.

Selain pada persoalan diatas, pengaruh game online terlepas dilakukan di warnet maupun dirumah sejauh belum memiliki self control yang baik akan berimbas pada menurunnya kualitas dan kuantitas nilai ibadah seseorang. Hal ini secara kongkrit dapat dilihat pada menurunnya nilai kedisplinan menjalankan ibadah tepat pada waktunya dan bahkan secara ektrim dapat meninggalkan kewajiban sebagai insan beragama. Islam sesungguhnya adalah agama yang sangat menghormati realitas obyektif dan realitas konkrit yang terdapat di sekitar dan dalam diri manusia (al-Islam din wâqi'iy). Ketika manusia menyukai keindahan, kecantikan, ketampanan, kelezatan dan kemerduan, Islam kemudian menghalalkannya, dengan syarat hal tersebut didapatkan dengan cara yang baik dan dilakukan dengan cara yang benar.

2. Menjaga Jiwa (Hifz al-Nafs)

Agama Islam mewajibkan umatnya untuk mencintai dan menjaga diri sendiri dengan cara menjaga jiwa sehingga dapat 
melawan segala godaan yang ada didunia ini dan mampu istiqomah terhadap ajaran agama. Salah satu cara memelihara jiwa yaitu selalu istiqomah dalam menjalankan ibadah dengan begitu maka jiwa kita akan selalu terjaga sebab senantiasa ingat kepada Allah. Selain itu memelihara jiwa juga bisa dilakukan dengan cara berbuat amal shalih. Amal shalih dapat diperbanyak dengan dengan beragam cara mulai dari berbuat baik kepada keluarga juga berbuat sesuatu yang bermanfaat bagi orang lain.

Terkait masalah game online maka para remaja atau para penggiat game online ini akan menghabiskan waktunya untuk bermain dan rasa sosial mereka akan menurun baik terhadap keluarga maupun terhadap masyarakat. Selain itu mereka akan menghabiskan waktunya untuk game online ini dan mereka lupa bahwa jiwa mereka juga mempunyai hak-hak maupun kewajiban yang harus ditunaikan.

3. Menjaga Akal ( Hifz-Aql)

Akal adalah seuatu yang membedakan manusi dengan makhluk lainnya. Inilah salah satu yang yang menjadi penyebab manusia merupakan makhluk dengan penciptaan terbaik dibandingkan makhluk lainnya. Akal akan membantu manusia untuk menentukan mana yang baik dan mana yang buruk. Penghargaan Islam terhadap peran akal terdapat pada orang yang berilmu, yang mempergunakan akalnya untuk memikirkan ayat-ayat Allah. Sebagaimana firman Allah SWT dalam QS. Ali Imran ayat 190-191 


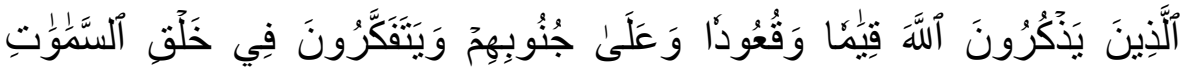

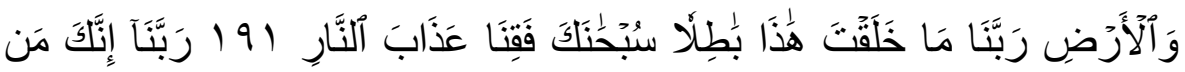

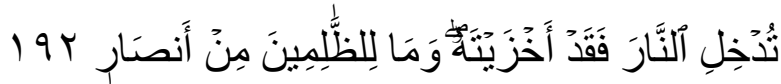

Artinya : "(yaitu) orang-orang yang mengingat Allah sambil berdiri atau duduk atau dalam keadan berbaring dan mereka memikirkan tentang penciptaan langit dan bumi (seraya berkata): "Ya Tuhan kami, tiadalah Engkau menciptakan ini dengan sia-sia, Maha Suci Engkau, maka peliharalah kami dari siksa neraka Ya Tuhan kami, sesungguhnya barangsiapa yang Engkau masukkan ke dalam neraka, maka sungguh telah Engkau hinakan ia, dan tidak ada bagi orang-orang yang zalim seorang penolongpun."

Bahwasannya untuk memelihara akal, maka syariat mengharamkan semua yang bisa merusaknya, baik yang maknawi (abstrak) maupun yang bersifat fisik. Misalkan tontonan yang bisa merusak akal termasuk game online. Selain membuat malas bekerja, game online juga bisa membuat manusia tidak mau belajar dan berpikir lagi. Anak-anak yang terlalu sering menggunakan gadget sejak dini terutama untuk bermain game, juga cenderung memiliki kepribadian yang rapuh, tidak mandiri, cengeng dan daya juang yang rendah.

4. Menjaga Keturunan (Hifdz al- Nasl)

Menjaga keturunan hal pokok yang harus dijaga untuk mewujudkan kemaskahatan bagi manusia. Menjaga keturunan adalah memelihara kelangsungan manusia dan membina sikap mental generasi penerus agar terhindar dari dari perbuatanperbuatan buruk yang bisa menjerumuskan mereka. Termasuk menjaga para remaja untuk selalu melakukan hal-hal yang positif 
yang bisa mendatangkan manfaat bagi mereka dan juga orang lain umumnya.

Para orang tua diharapkan bisa mendidik anak-anaknya menjadi pribadi yang baik yang bermanfaat bagi orang lain, menjaga mereka dari perbuatan yang tidak berguna dan mengarahkan mereka untuk melakukan hal-hal yang positif. Anakanak yang sudah kecanduan game online cenderung tik peduli dengan nasehat orangtua bahkan sering membantah perintah orang tua. Ini menjadi tugas orang tua untuk memelihara anakanaknya dan tidak merusaknya dengan membiarkan anak-anak menghabiskan waktunya dengan bermain game.

5. Menjaga Harta (Hifz al-Mal)

Harta merupakan kebutuhan pokok dalam kehidupan dimana manusia tidak akan bisa terpisah darinya. Manusia termotivasi untuk mencari harta demi menjaga eksistensinya dan demi menambah kenikmatan materi dan religi, dia tidak boleh berdiri sebagai penghalang antara dirinya dengan harta. Namun semua motivasi ini dibatasi dengan tiga syara, yaitu harta dikumpulkan dengan cara yang halal, dipergunakan untuk hal-hal yang halal dan dari harta ini harus dikeluarkan hak Allah dan hak orang lain. Terkait dengan game online, maka pemeliharaan harta ini juga penting, karena dalam permainan ini juga sering terjadi penipuan dan ini bertentangan dengan maksud dari pemeliharaan harta. Selain itu game online adalah sesuatu yang kurang bermanfaat dan ini juga bertentangan denga syarat memperoleh 
harta yang kedua yaitu menggunakan harta untuk hal-hal yang halal dan juga bermanfaat.

\section{KESIMPULAN}

Game atau permainan sesungguhnya adalah bagian dari sarana hiburan dan sarana melepas lelah. Islam mewajibkan kepada umatnya agar mengabdikan seluruh hidupnya hanya untuk beribadah kepada Allah swt. Itulah orientasi tunggal yang harus dipegang oleh kaum muslimin dalam menjalani kehidupan. Dalam agama Islam game online atau permainan menjadi haram ketika ada unsur-unsur haram di dalamnya. Untuk itu, perlu diperhatikan batasan-batasan berikut berikut: (1) Memastikan bahwa materi permainan yang disajikan tidak bertentangan dengan prinsipprinsip pokok dalam agama Islam, baik diranah akidah, akhlak maupun ibadah. Hendaknya game tidak bertentangan pula dengan unsur-unsur kebudayaan Islam dan kebudayaan local yang telah mengakar di tengah-tengah masyarakat. Juga tidak bertentangan dengan tujuan ditetapkannya hukum Islam (maqasid al-syariah). Yang harus diperhatikan adalah dewasa ini banyak jenis permainan yang membawa agenda terselubung (hidden agenda) dalam merusak moral generasi muda bangsa kita.

(2) Hendaknya game dimainkan sesuai dengan porsinya, jangan sampai hiburan menyita seluruh waktu, menghalangi dari aktifitas lainnya dan mengambil waktu-waktu belajar serta bekerja. Permainan jangan sampai melalaikan seseorang dari tugas-tugas pokoknya dalam beribadah dan dalam rumah tangga. Selain itu, jangan sampai membuat orang lupa dari yang lebih 
penting, seperti olahraga fisik untuk menyehatkan badan, dan juga sampai seseorang terjerumus dalam kecanduan.

\section{DAFTAR PUSTAKA}

al-Zarqa, Muasthafa Ahmad. Hukum Islam dan Perubahan Sosial: Studi Komparatif Delapan Mazhab Fiqh. Jakarta : Riora cipta, 2000.

Asosiasi Penyelenggara Jasa Internet Indonesia (APJII), "Responden Survey Nasional Penetrassi Pengguna Internet 2018".

Djamil, Fathurrahman. Filsafat Hukum Islam. Ciputat: Logos Wacana Ilmu, 1999.

Farras, Bernhart. "10 Game Online Android Terbaik dan Terpopuler Untuk Mabar", www.cnbcindonesia.com, 2019.

Hosen, Ibrahim. Bunga Rampai dari percikan Filafat Hukum Islam. Jakarta: Yayasan Institut Ilmu al-Qur'an (IIQ), 1997.

Irawan, Eka Nova. Pemikiran Tokoh-tokoh Psikologi dari Klasik sampai Modern. Yogyakarta: IRCisos, 2015.

Jogiyanto, HM. Sistem Informasi Keperilakuan. Yogyakarta: Andi Offet 2007.

Raisuni, Ahmad. Nazhariyat al-Maqasyid 'Inda al-Syatibi. Rabath: Dar al-Aman, 199.

S Young, Kimberly. Internet addiction: A Handbook and Guide to evaluation and treatment. Hoboken, NJ: John Wiley \& Sons, 1999.

Syadali, Ahmad dan mudzakir. Filsafat Umum. Bandung: CV Pustaka Setia, 2004.

Walgito, Bimo. Psikologi Sosial : Suatu Pengantar. Yogyakarta : Fakultas Psikologi UGM, 1980. 